Guide lines for applieations for fellowships have boen established and are available at the International Brain Research Organization's Secretariat, Unesco House, Paris; a numbor of International Brain Research Organization fellowships as well as researeh teams organized by the International Brain Organization are already in operation.

Certain projects are assignod to ad hoc committees or are the direct responsibility of the Secrotariat. Into the first group falls the preparation of a survey of manpower and laboratory facilities in brain sciences. This projoct is under the guidance of Dr. H. H. Jasper, with Dr. Stella Doignan as survey officer, and will, in time, compile a directory of mon of science working in the various disciplines of brain sciences as well as of the laboratories available to them. A questionnaire with detailed inquiries as to the scientific intorests, accomplishments and laboratory facilities are boing sont out to all members of the International Brain Research Organization. This survey is essential for the operation of the research team and fellowship programmos and for many other activities of the International Brain Research Organization. Moreover, the Secrotariat has been given the responsibility for the preparation of a hand-took on growth and development of the nervous system, which was considered by tho Central Council an essential and primary task for the stimulation of research in this field. A planning session in March 1962, under the chairmanship of Dr. L. Floxner, in co-operation with the World Health Organization and the Council for International Organizations of Medical Sciences was held in Geneva. The Central
Council has also expressed great interest in the subject of Brain Mechanisms of Learning and Memory.

In addition to its affiliation with Unesco as a nongovernmental agency on a consultative basis, the International Brain Research Organization has official relations with the World Health Organization and various other international organizations. The presonce of the representatives of these various international bodies and unions at tho meetings of the Central Council has been greatly appreciated and found to bo of great use to the International Brain Research Organization.

In addition to the subvention by the Department of Natural Sciences of Unesco, the major support for specific projects, such as the regional seminars, symposia and the world survey, has come from the U.S. Public Health Service through international grants. Funds have also been provided for specific purposes by tho National Science Foundation and the National Aeronautic and Space Administration. In addition, private individuals interested in brain sciences have contributed to the unassigned funds of the International Brain Research Organization.

Detailed information about the objectives and activities of tho International Brain Research Organization may be found in the IBRO Bulletin, published several times during the year by the Secretariat. Information may also be obtained directly from the International Brain Research Organization's Secretariat at Unoseo House, Place de Fontenoy, Paris. The Secretariat would appreciate any suggostions for the further development and implementation of international interdisciplinary brain research.

\title{
PLACE OF TAXONOMY IN THE TEACHING OF BIOLOGY
}

A SYMPOSTUM on the above subject was organized by the Systematics Association in the Univorsity of Birmingham, by invitation of Prof. J. Heslop-Harrison, on January 26.

Prof. J. G. Hawkes (University of Birmingham) pointed out that, up to about eighty years ago, taxonomy comprised the whole of botany, but that from then until the mid-thirties it suffered a decline, being largely replaced by the nower disciplines of plant physiology, ecology and genetics. At tho present timo, taxonomic teaching and research have come back, to occupy a place of importance equal to those other disciplines.

The place of taxonomy in a botany course must depend on how it is taught and on the interests of the lecturer. Most teachers have now moved away from giving descriptions of one family after another. It is necessary now to show students something of the great diversity within the plant kingdom, yet they cannot be expected to learn more than a fraction of this in a three-year course. Consequently, they must be given a reasonablo knowledge of the British flora, and shown the theoretical bases of taxonomic research, and their taxonomic investigations linked with other aspects of botany.

The links between taxonomy and plant morphology and anatomy are obvious. No less important is the relation between taxonomy and plant ecology, for one must be able to identify the plants with which ono is working in the field. Discussion of ecological and geographical barriers in species formation gives the student a background of ecological thought to apply whon examining plants in field or herbarium.

Taxonomic teaching should link closely with genetics and cytology, since these investigations can show by experiment how plants are rolated to each other, and how they are evolving. Attention should be directed to cytological criteria in classification. Chromosome investigations in natural and artificial hybrids can be most stimulating, and should include examples from cultivated plants, where cytologists and plant breeders have been able to elucidate the evolutionary relations of cultivated to wild species. Though relatively few plant species have been investigated genetically, enough knowledge exists to provide an understanding of tho different sorts of variation. Many geneticists have gone ovor to the field of experimental taxonomy, yet would be surprised to be told they were engaged in taxonomic research.

Too much stress should not be laid on nomenclaturo, though this aspect must not be wholly neglected, and can be linked with the history of botanical thought. The value of biomotrical and statistical investigations needs no stressing, and these can profitably be pursued by students who are mathematically inclined. Latterly it has become more and more possible to draw on comparative invostigations in plant biochomistry and serology to holp in classifying both species and higher categories. Thus, students can use the taxonomic approach to fit otherwise unrelated information into a unifying framowork of ideas. Without such a focal point, work in other fields is very liable to be incorrectly assessed or invalidated.

In conclusion, I'rof. Hawkes gave his ideas on how taxonomy might be taught in sixth forms in schools, and an outline of the taxonomy course ho himself has used in Birmingham.

Prof. O. W. Richards (Imperial College of Science and Technology) reminded his audience of the varied opinions as to how zoology should be taught and said his viow was that not all students should recoive the same type of training, but that the greater the variety of course available the better it would be. However, in a programmo concerned mainly with funetions and processes common to many groups, there was need of a short course in taxonomy, to inculcate an understanding of the variety of creatures, whereas in ono organizod around the ideas of classification and evolution there was less nood for formal instruction 
in taxonomy at the undergraduate-level. He had always been in a department with the latter orientation, and hence proceeded to deal with this aspect.

Practical considerations regarding animal material arise. In most birds, many mammals, butterflies and mosquitoes, the greater part of the primary taxonomy has already been done; but in most insect groups outside and many within Europe it has not, and in these fields little manpower ean be spared for cytogenetic investigations and the like. On the other hand, adequate collections of birds and mammals can only be housed in large museums, whereas small animals can be collected and stored without great expense, and conveniently worked by student or amateur. An interest in such work is regarded as a favourable point for the admittance of a student to the Imperial College of Science and Technology.

In the Department of Zoology and Applied Entomology at the Imperial College of Science and Tochnology, elementary students receive a course in comparative anatomy, in which the principles of classification and characterization are learned. Concurrently they study botany with a taxonomic bias, on account of the importance of plants to those working with insects and nematodes which attack them. In vacation field-work, much collecting and identifying is done. Third-year students receive instruction that is more overtly taxonomic, and in the intor-related fields of geographical distribution, genetics and evolutionary theory.

Imperial College is favourably placed, on account of its proximity to the British Museum (Natural History) and the Commonwealth Institute of Entomology, for tho training of postgraduate students in taxonomy, and often receives such students sent by overseas Governments. A student will take on a group of perhaps 50 species from a chosen area, for example, India, and will catalogue, reclassify and redescribe the genera and species concerned, making comparisons all the time with matorial from outside his area. He will make a full, illustrated morphological description of a typical species in his group. Although good taxonomists are more born than made, the most naturally born taxonomist can be introduced to ideas with which he may be unfamiliar, and he will receive instruction in, for example, theories of variation and of sympatric and allopatric distribution as affecting the status of taxa. The student is encouraged to compound his classification of as wide a corrolation of characters as possible, differences in both external and internal structure of adult and immature form, differenees in distribution, habit, physiology and ecology, etc.

At the present time much identification of species is done by people without degrees. From this it has been argued that such work requires only a limited training, but what is more likely is that too few men and womon receive tr aining at a university.

Prof. P. C. Sylvester-Bradley (University of Leicester) reminded those present that biology as a scionce had beon characterized by phases of explosive activity. The best known was triggered off by Darwin. Another began in 1938, when Sir Julian Huxley founded the Systematics Association and initiated the 'now systematics', and when complementary reviews were published by Rensch, Mayr and Simpson which established the synthetic theory of evolution. Disciplines which previously had been selfcontained spread into other fields and, by cross-fertiliza. tion, infused new vigour into old systems. A science which had become over-specialized found itself integrated, young and adaptable.

The most recent explosion of ideas culminated in 1962 with reports on the nature of the genetic code; and just as 1938 gave birth to the 'new systematics', so has 1962 produced a 'new biology'. Every university in Britain is seeking to integrate this new biology into its teaching and research programme, but is discovering obstacles to such integration.
The new advances foreseen lie in the field of molecular biology, and if these are to be applied to the whole field of human endeavour they must be integrated with the whole of biological science. This cannot occur if we just add new departmental walls to our existing structure; we need a discipline to exploit the common ground linking the old with the new. Twenty-five years ago systematics led to the synthesis of evolutionary theory; Can it play a similar part again?

An important development was the publication, two years ago, of Simpson's Principles of Taxonomy. Simpson draws a distinction between 'taxonomy' dealing. with the principles of classification, and 'systematics', as concerning the investigation of diversity and the process of differentiation. It is in this latter sense that systematics stands out as a potential integrating force: it can be applied at all levels, and is linking the small with the great. An example is in the field of genetics where 'epigenetics' deals with the investigation of differentiation at the level of the molecule, the cell, the organism, and 'population genetics' at the level of the population and the species.

Systematics must also embody the discipline of comparison: comparative morphology, physiology, ethology and biochemistry all contribute to the new systematics, and thus find their way into classification and form part of taxonomy. The recent conference at Kansas on taxonomic biochemistry, physiology and serology, explored how those comparative aspects can be applied to taxonomic problems. But if systematics is to act as an integrating force in biology it must not only embody now ideas but also initiate its own programme of discovery, for it is necessary to know much more about the mechanisms of differentiation at all levels and how they have come about. Such a programme of functional and evolutionary systematics will hold the key to integration, and may well yield answers to urgent problems concerning the future of mankind.

Palæontology is sometimes regarded as only boing on the fringe of biology, yet its full integration can be achieved if systematics as interpreted here is applied to its teaching. A palieontological systematist would be investigating the process of differentiation in time, and his problems need genetical, physiological and taxonomic participation. No palæontologist can understand his subject if he is not a biologist, and no university can omit biology from his training. What is true of this is true of every branch of biology; the walls must come down.

In opening the discussion, Prof. H. Heslop-Harrison said that this was an important time to consider the place of taxonomy in the teaching of biology, for throughout Britain there are moves toward new ways of presenting the subject, arising from the enormous accretion of new material, and an awareness that subdivision insulates complementary branches which should feed ideas one to another. Taxonomists must state what their contribution is and how it should be made, otherwise their opportunity was likely to disappear.

We need a realistic assessment of the place of taxonomy in biology in general. That its relative importance has declined is beyond denying, for at one time it was virtually the whole of biology; yet a case can still be made for the view that its significance as a unifying force is all pervasive for, as Simpson has said, taxonomy is at once the most elementary and the most inclusive part of biology. It has the potentiality for gathering data from all branches of biology and of providing the means of orientation: its method is the principal one for the investigation and codification of organic variation and as such it is indispensible.

Taxonomists should so order their work that other biologists find tools that can contribute to their own investigations. Lack of esteem for the discipline might be caused by those who are over-obsessed with nomenclatural wrangles, and by those who will not rationalize 
their methods and adopt precise ways of thought. Yet there is no need for the investigation of organic variation to be based on subjective foundations: it can be treated as rigorously as any physiological problem, and its results can be stated in almost as precise terms. Shorn of legalism and imprecision, taxonomy ean discharge its unifying function in the new biology. In the context of biological teaching, it can form the principal agency through which the student can learn of the diversity of living things, the pattern of diversity and the evolutionary mechanisms through which that pattern has arisen.

Dr. P. H. A. Sneath supported Prof. Sylvester-Bradley on the central role of systematics in relating the small and the large scale, molecular and population biology. These sciences will produce a flood of information which will need correlation and classification, and mathematical methods would be invaluable here. Nomenclature should be taught simply with emphasis on the reasons for the rules, which were seldom understood by students. Dr. A. J. Cain (University of Oxford) said that intuition in taxonomy, meaning the rapid appreciation of many characters and their comparison, was perfectly respectable; but when authors included irrational biases, their work was deservedly in disrepute. Prof. Heslop-Harrison said that correlations put intuitive results into an analytical form. Prof. D. G. Catcheside (University of Birmingham) said that problems of classification were encountered in many fields outside biology, for example, librarianship and organic chemistry, and that all biology students should be introduced to these problems in their first year. Those who are potential specialists would develop their specialization later, after making a particular investigation of those parts of biology most basic to systematics, especially genetics, cytology and ecology. Dr. Cain spoke of the use in Oxford of a block-course of a solid fortnight's taxonomic teaching, in which students made more progress than in the same amount of time spread out. Prof. J. G. Hawkes said that in the Botany Department in the University of Birmingham they offered four five-week block courses of taxonomy options for final-year students, enabling those students to concentrate their thoughts on taxonomic lines for that period. Dr. L. H. Finlayson (University of Birmingham), replying to the chairman's question on the possible place of taxonomy in the new integrated syllabus in biology in Birmingham, said there was very little time in the first-year course, but that it was hoped to present some of the basic taxonomic problems in the investigation of the physiology of species, etc. In later years there will also be a time problem, but this can be overcome by teaching taxonomy with morphology and ecology in field courses. Prof. Catcheside said that even in the first year some aspect of the subject should be investigated in depth: Dr. Finlayson agreed, commenting that no course could be completely comprehensive without being superficial. Prof. O. W. Richards said that integra- tion might be a polite synonym for omission: whatever is done, biology is now too large to be taught in three or even five years. The continued teaching of classical biology and practice of primary taxonomy were essential supports for agriculture. Dr. Sneath asked whether it would be possible to think ahead to what biologists would be doing in fifty years' time so that teaching methods could be devised accordingly. A wide view of the variety of Nature may be very stimulating and encourage students to think for themselves. The new American High School syllabus books may suggest the sort of wide approach needed.

Dr. Cain, summing up, said there was clearly very considerable agreement that all students must receive some instruction in the range of diversity in the plant and animal kingdoms, its origin, nature and fate in evolution if they were to call themselves whole biologists. It was also agreod that this was a time when all must rethink their roles, to fit in with the extremely good new developments in biological teaching and research; though unfortunately some so-called rethinking masked a design to gain greater advantage for some fields of investigation at the expense of others.

Systematics could offer a broad and comprehensive view, backed by experiment, of the organism as moulded by selection, speciation, and evolution for particular modes of life. Every living thing was as much the product of these factors as of those of gene-action, development, intermediate metabolic activity, regulation and the other basic biochemical and physiological processes, and all aspects must be investigated.

Another contribution that could be made at university level was a thorough investigation of techniques of comparison of all forms, of mathematical as well as descriptive techniques, of technical terms and of scientific nomenclature, and systematics could institute a really searching investigation. Recent developments in numerical taxonomy were here of particular importance.

A third aspect, rightly stressed by Prof. O. W. Richards, was the mapping of the diversity of the animal and plant kingdoms. The number of new species, each a different solution of the problem of living and a source of information for all sorts of biologists, even in Britain was appalling. This was a matter of the greatest seriousness, and the Royal Society had set up a committee to consider the provision of taxonomists in Britain, since it was often difficult or impossible to get the accurate identifications needed for all good work.

Systematics, in all these aspects, had positive contributions to make to university teaching; but in ordor that such contributions can be made, it must receive as adequate recognition as that accorded to other branches of the subject. Stultification of any one approach could only lead to the impoverishment of the whole of biology.

G. J. KERRICH

\section{PRACTICAL SCIENCE IN SCHOOLS*}

$\mathrm{T}$ HE report on Practical Work in School Science, by J. F. Kerr, fully deserves the attention it will receive from teachers of science in schools pursuing a grammar school type of curriculum, as well as from members of the Boards which hold examinations for the General Certificate of Education at Ordinary and Advanced Levels. It should also receive consideration by all people who are concerned with education since it reveals an urgent need for a complete re-assessment of the practical aspects of science

* Practical Work in School Science: an Account of an Inquiry sponsored by the Gulbenkian Foundation into the Nature and Purpose of Practical Work in Schol Science Teaching in England and Wales. By J. F. Kerr, assisted by H. F. Boulind, M. J. Rolls, D. W. Scott
(Leicester: The University Press, 1963.) 58 . teaching in which "the pattern of work has become inflexible, repetitive, and outmoded and often inadequately integrated with the theory".

The inquiry was financed by a grant to the University of Leicester by the Trustees of the Calouste Gulbenkian Foundation. In carrying it out, the chief author had the assistance of four other lecturers in science teaching methods at university departments of education, and they could refer to an Advisory Committee on which representatives sat from the Ministry of Education and the then Science Masters' Association and Association of Women Soience Teachers. The inquiry was conducted mainly by means of questionnaires and personal visits; 701 teachers 